UDC $614.1 ; 614.4$

DOI: $10.21668 /$ health.risk/2021.3.02.eng

Research article

\title{
ON ESTIMATING THE ADDITIONAL INCIDENCE OF COVID-19 AMONG POPULATIONS EXPOSED TO POLLUTED AMBIENT AIR: METHODOLOGICAL APPROACHES AND SOME PRACTICAL RESULTS
}

\author{
N.V. Zaitseva ${ }^{1}$, I.V. May ${ }^{1}$, J. Reis ${ }^{2}$, P. Spencer ${ }^{3}$, D.A. Kiryanov ${ }^{1}$, M.R. Kamaltdinov ${ }^{1}$ \\ ${ }^{1}$ Federal Scientific Center for Medical and Preventive Health Risk Management Technologies, 82 Monastyrskaya \\ Str., Perm, 614045, Russian Federation \\ ${ }^{2}$ University of Strasbourg, Faculté de Médecine, Strasbourg, 67000, France \\ ${ }^{3}$ Oregon Health \& Science University School of Medicine, Portland, Oregon, 97201, USA
}

We estimate quantitatively the influence of ambient air pollution on SARS-CoV-2 spread among populations in six cities in the Russian Federation. These cities are among priority ones as per air pollution and are included in the "Clean air" Federal project (Bratsk, Krasnoyarsk, Norilsk, Omsk, Cherepovets, and Lipetsk).

Our hypothesis was that dynamic features of the infection spread would be different from an expected model of its epidemiologic process under exposure to environmental pollution. Regression and correlation analysis was performed for relationships between a daily deviation in actual incidence from a basic epidemiologic scenario and the average daily concentrations of chemicals in ambient air. The initial data were results obtained from instrument measurements of ambient air quality in the examined cities (approximately 10.8 thousand measurements covering 29 chemicals) and the daily incidence of COVID-19 from April 18, 2020 to July 31, 2021 (77,337 cases).

An authentic correlation between COVID-19 incidence and chemical concentrations in ambient air was detected in all six examined cities. The contribution of air pollution to COVID-19 incidence rate amounted to $5.0 \pm 2.6 \%$ in five cities (Krasnoyarsk, Norilsk, Omsk, Cherepovets, and Lipetsk) over the examined period. In Bratsk, this value was about $33 \%$ and it requires additional research for either confirmation or correction. Growth in COVID-19 incidence in the examined territories is associated with particulate matter $\left(P M_{10}, P M_{2.5}\right)$ and some other chemicals that can irritate the airway directly or indirectly (sulfuric acid vapors, hydrogen chloride, formaldehyde, hydrogen sulphide, etc.). Target levels were substantiated for several priority chemicals; should these levels be achieved, one would predict a decrease in COVID-19 incidence by more than $1-3 \%$ in the examined cities.

We propose that population morbidity and mortality caused by COVID-19 require further studies, including those combined with medical and biological examination regarding efficiency of vaccination and post-vaccination immunity persistence on territories with elevated environmental pollution. This research is vital due to the considerable global medical and demographic losses during the COVID-19 pandemic and the latest research works providing evidence of a correlation between air pollution and spread of the disease, its severity, clinical course and outcomes.

Key words: COVID-19, ambient air pollution, chemicals, target levels.

(C) Zaitseva N.V., May I.V., Reis J., Spencer P., Kiryanov D.A., Kamaltdinov M.R., 2021

Nina V. Zaitseva - Academician of the Russian Academy of Sciences, Doctor of Medical Sciences, Professor, Scientific Director (e-mail: znv@fcrisk.ru; tel.: +7 (342) 237-25-34; ORCID: https://orcid.org/0000-0003-2356-1145).

Irina V. May - Doctor of Biological Sciences, Professor, Deputy Director responsible for research work (e-mail: may@fcrisk.ru; tel.: +7 (342) 237-25-47; ORCID: https://orcid.org/0000-0003-0976-7016).

Jacques Reis - Doctor of Medical Sciences, Associate Professor (e-mail: jacques.reis@wanadoo.fr; tel.: +33 368850000 ; ORCID: https://orcid.org/0000-0003-1216-4662).

Peter S. Spenser - Professor of Neurology and Occupational Health Sciences (e-mail: spencer@ohsu.edu; tel.: +1 503-494-1085; ORCID: https://orcid.org/0000-0003-3994-2639).

Dmitrii A. Kiryanov - Candidate of Technical Sciences, Head of the Department for Mathematical Modeling of Systems and Processes; Associate Professor at Department for Human Ecology and Life Safety (e-mail: kda@fcrisk.ru; tel.: +7 (342) 237-18-04; ORCID: https://orcid.org/0000-0002-5406-4961).

Marat R. Kamaltdinov - Candidate of Physical and Mathematical Sciences, Senior researcher acting as the Head of the Department for Situation Modeling and Expert and Analytical Management Techniques Laboratory (e-mail: kmr@fcrisk.ru; tel.: +7 (342) 237-18-04; ORCID: http://orcid.org/0000-0003-0969-9252). 
The COVID-19 pandemic has resulted in grave damage to the world's population, as well as to global economies and finance. Detailed studies on reasons for the occurrence and spread of disease, its severity and modifications in its clinical course, became one of the most vital trends in scientific research in 2020-2021.

The integration of long-term epidemiologic and experimental data suggests that environmental pollution would serve to favor the spread of SARS-CoV-2 virus and negative health outcomes of COVID-19 [1-5]. Indeed, previous research focusing on respiratory viruses has provided evidence that air pollution can contribute to elevated morbidity and mortality primarily caused by communicable diseases [6-9]. Research accomplished during the first COVID-19 wave described detected direct authentic correlations between dust particles (including $\mathrm{PM}_{10}$ and $\mathrm{PM}_{2.5}$ ), nitrogen oxides, ozone, and other pollutants contained in ambient air and COVID-19-related mortality and morbidity [10-14]. There are assumptions in some published works that air pollutants, primarily finely-dispersed dusts, can enhance coronavirus spread since they absorb the culpable virus (SARS-CoV-2) on the surface of particles $[15,16]$.

According to data provided by the World Health Organization (WHO), all sizes of aerosol particles carrying infectious virus can deposit directly on the mucosa of the respiratory tracts (direct contacts); additionally, the agent could contaminate surfaces or objects (fomites) and thereby be transmitted to mucosa (indirect contacts) [17]. Viable SARS-CoV-2 virus has been detected on surfaces for several hours or even several days depending on environmental conditions [18]. Therefore, when solid or liquid droplets (as a disperse phase) occur in air (as a disperse medium), there is greater potential for the virus to spread.

These assumptions have been confirmed with epidemiologic research. Using results obtained by analyzing medical and demographic statistical data collected in more than 3 municipal settlements in the USA, Wu and colleagues
[19] established that an increase of $1 \mathrm{mg} / \mathrm{m}^{3}$ in finely dispersed $\mathrm{PM}_{2.5}$ dust in ambient air resulted in an $8 \%$ increase in mortality due to COVID-19 (95\% confidence interval was 2-15\%). These authors assumed that both short-term (acute) and long-term (chronic) exposure to $\mathrm{PM}_{2.5}$ dust would be a risk factor.

Setti and associates revealed an authentic correlation between excessive daily $\mathrm{PM}_{10}$ levels and initial COVID-19 spread in 110 provinces in Italy [20]. Additionally, Chinese and British scientists used ecologic and medical data collected in 120 cities in the People's Republic of China (approximately 58 thousand COVID-19 cases) to develop multifactor mathematical models that described positive correlations between the daily number of confirmed COVID-19 cases and ambient concentrations of finely dispersed dusts $\left(\mathrm{PM}_{2.5}, \mathrm{PM}_{10}\right)$, nitrogen dioxide, and ozone in ambient air averaged over a 2-week period [21]. The authors indicated it was vital to take necessary actions aimed at reducing air pollution since it would help minimize disease incidence.

Several studies have found that air pollution not only promotes the spread of SARSCoV-2 but also compromises the removal of airway pathogens, diminishes overall immunity and aggravates cardiovascular or lung diseases [22-25]. Bourdrel and colleagues (2021) showed that air pollution might be related to increased COVID-19 severity and lethality in subjects with chronic diseases, such as cardiopulmonary disease and diabetes mellitus They noted that exposure to polluted air resulted in a weaker immune response that promoted viral entrance and replication in the body. Besides, viruses can persist in ambient air due to complex interactions with solid particles and gases. Such interactions vary according to chemical structure, particle electric charge, and meteorological parameters such as relative humidity, ultraviolet radiation, and temperature [26].

A wide-scale study of more than 27.6 thousand patients with COVID-19 showed that the highest mortality occurred among patients 
who, prior to SARS-CoV-2 infection, suffered from cardiovascular diseases, immune and metabolic disorders, respiratory diseases, cerebrovascular diseases, or cancer [27].

All the aforementioned data are in line with results obtained by German researchers [28] who emphasize that the epidemic process, while uniform, resulted in significant differences in COVID-19 prevalence in European countries with similar and efficient public healthcare systems and similar population structures. Long-term exposure to adverse environmental factors in a period prior to the epidemic is considered a possible reason for the higher incidence of COVID-19 in some countries. Drinking water chlorination, environmental pollution with pesticides and persistent organic pollutants, among other factors, were considered to be risk factors that suppress immune function and thereby increase susceptibility to viral infection.

Results obtained via spatial analysis of fatal COVID-19 cases in 66 administrative districts in Italy, Spain, France, and Germany indicate that 3,487 of 4,443 (78 \%) deaths occurred in 5 regions located in northern Italy and central Spain. Importantly, attendant orographic features compromised the efficient dispersion of airborne pollutants, such that the highest nitrogen dioxide concentrations were detected in the same five regions [29]. The authors proposed that longterm exposure to nitrogen dioxide contributed significantly to the elevated COVID-19 mortality in these regions.

Given that poor environmental quality, especially of ambient air, appears to exert both direct and indirect influences to promote COVID-19 spread and associated mortality, we employ our expertise in environmental hygiene to examine the Russian experience. Ambient air quality in many large cities in the country is rather poor due to chemical admixtures occurring in quantities that exceed hygi- enic standards; this includes airborne pollutants such as dusts, especially $\mathrm{PM}_{10}$ and $\mathrm{PM}_{2.5}$, nitrogen oxide, and nitrogen dioxide among other pollutants that appear to elevate risks of COVID-19 spread [30-32]. The subject is of special relevance to the populations of Russian cities where ambient air is heavily polluted, including those listed within the "Clean air" Federal project, such as Krasnoyarsk, Bratsk, Cherepovets, Norilsk, and others [33-35]. Coal is a primary energy source in cities located in the Siberian Federal District in Russia where prevalent climatic and meteorological factors prevent efficient dispersion of emissions from energy-producing objects, industries, transport, and heating sources in private households. These factors combine to result in the accumulation of airborne pollutants in the bottom layers of the atmosphere, that is, the layers from which people breathe air.

The Russian Federation is currently assessing the correlation between quality of the environment and morbidity and mortality of COVID-19 ${ }^{1}$. Here, we quantitatively assess the relationship between COVID-19 morbidity and mortality and several environmental parameters, the results of which can be used to regulate sources of air pollution. This is especially important for economic entities, notably businesses, since the COVID-19 pandemic has resulted in significant losses of working days among the employable population due to temporary inability to work. Figure 1 shows that the working population prevailed among COVID-19 patients (40.4\%), workers accounting for $27.8 \%$ among them; medical personnel, $9.8 \%$; office workers, $7.7 \%$; and personnel employed at educational establishments, $2.8 \%$.

Our research goal was to quantitatively assess the influence of ambient air pollution on SARS-CoV-2 spread among selected urban populations living in Russia under unfavorable sanitary-hygienic conditions.

\footnotetext{
${ }^{1}$ Does air pollution influence mortality caused by the new coronavirus infection? Available at: http://cgon.rospotrebnadzor.ru/content/62/4262/ (August 18, 2021).
} 


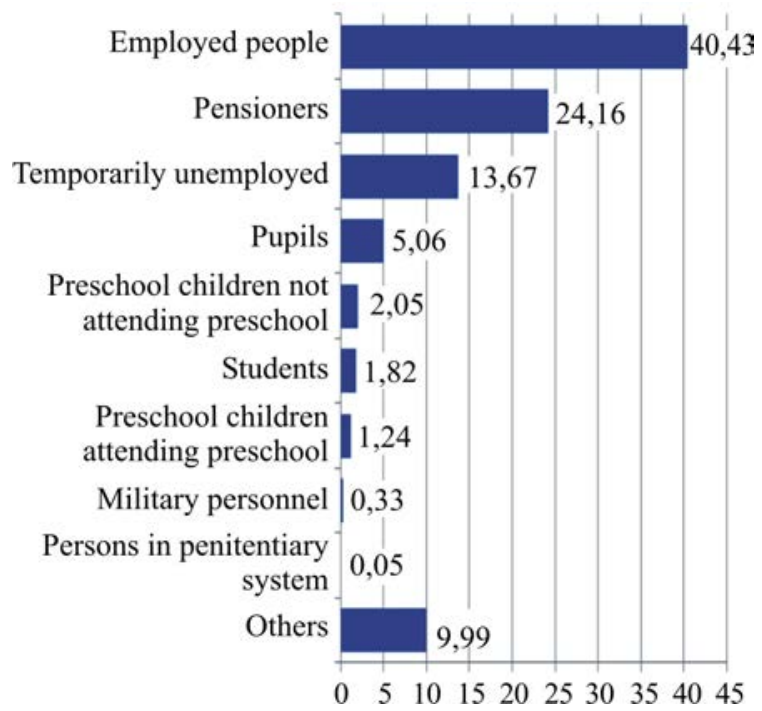

Figure 1. Composition of COVID-19 patients in Russia by occupation or social status (2020), \% [36]

Research Design. The research design was built on the assumption that air pollution could change the epidemiologic process due to sorbed viruses being carried on solid particles, on the one hand, and particulate irritation of mucosa and weakened barrier functions of the respiratory organs, on the other hand. Essentially, it was assumed that air pollution created environmental conditions under which dynamic features of the infection spread were different from any expected scenario that corresponded to a standard model of the epidemiologic process.

It should be noted that an epidemiologic process model (a basic scenario of the infection spread) has a complex structure and should take into account certain peculiarities typical for a given territory or a settlement, such as population density, inter- and intraterritorial migration, peculiarities related to anti-epidemic activities organization, among other considerations. Building such a model requires special studies and is beyond the framework of the present research and its tasks.

Data and methods. COVID-19 incidence was quantitatively estimated based on an analysis of cause-effect relations between the daily growth in the number of cases and air pollution rates in six cities listed in the "Clean air" Federal project program, namely Bratsk, Krasnoyarsk, Norilsk, Omsk, Cherepovets, and Lipetsk (Figure 2).

The main sources of pollution in the studied cities are the objects of the mining and metallurgical industry, in Siberian cities (Bratsk, Norilsk, Krasnoyarsk) there are also heat power facilities operating on solid fuels.

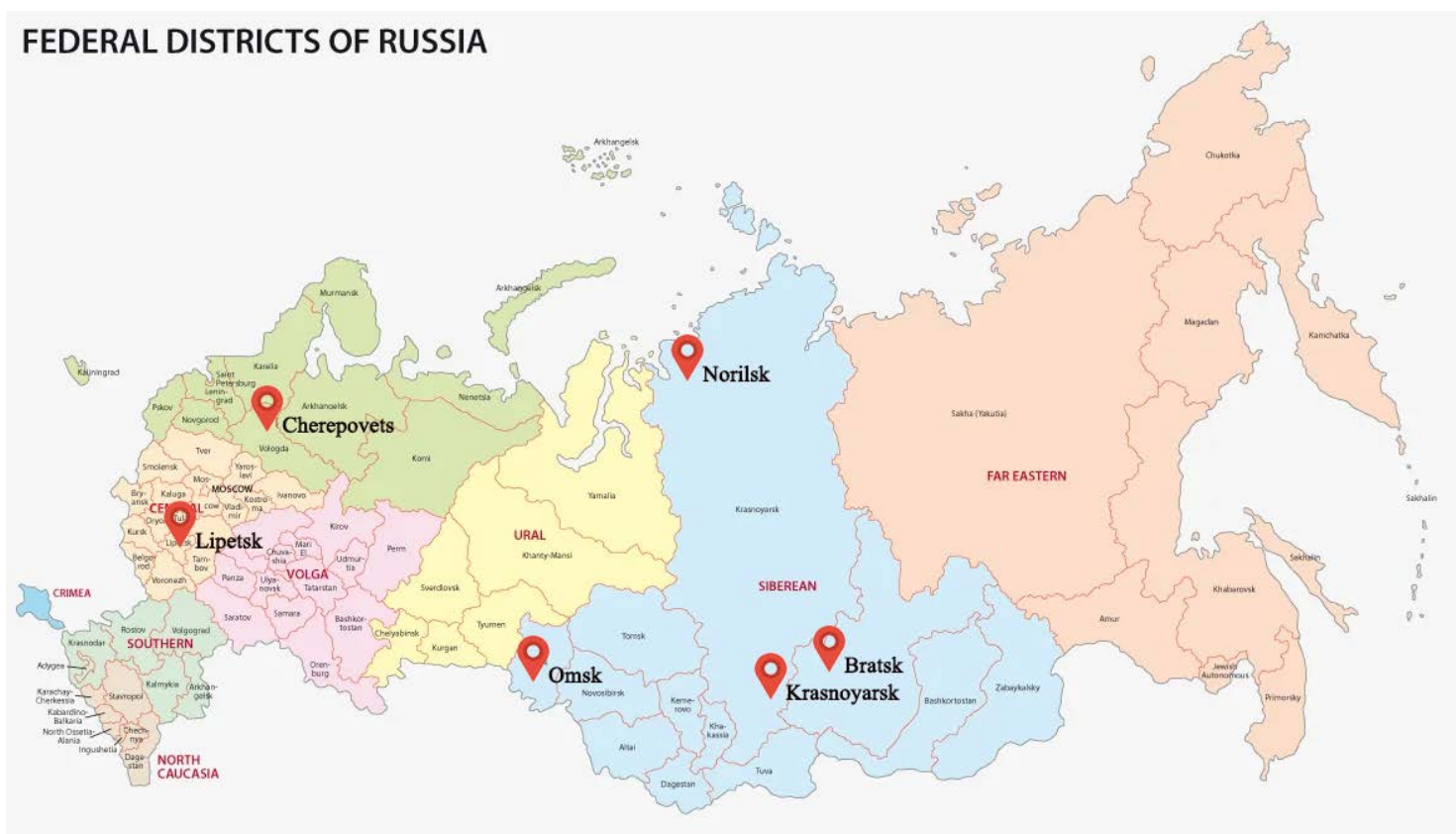

Figure 2. Location of the studied cities on the map of the Russian Federation 
Results obtained via daily instrumental measurements of chemical concentrations in ambient air in these cities were taken as initial data on ambient air quality. Measurements were accomplished within social-hygienic monitoring activities by certified laboratories of the Centers for Hygiene and Epidemiology in Irkutsk region (Bratsk), Krasnoyarsk region (Krasnoyarsk and Norilsk), Omsk region (Omsk), Vologda region (Cherepovets), and Lipetsk region (Lipetsk). All monitoring posts were located in urban residential areas. Samples were taken as per the most comprehensive program (4 times a day). Comparable and certified sampling and measurement procedures were applied in each examined city.

The research covered all particulate matter and admixtures which, according to data available in relevant scientific literature, can exert a negative influence on airway function and/or the immune system. Overall, our analysis included 10.8 thousand instrumental measurements of 29 entities, including $\mathrm{PM}_{10}$ and $\mathrm{PM}_{2.5}$ with non-differentiated structure, finely dispersed particles with known chemical structure (oxides of aluminum, nickel, copper, chromium, and poorly soluble fluorides) soot, benzopyrene, nitrogen dioxide, sulfur dioxide, hydrogen chloride, sulfuric acid, and aromatic hydrocarbons (benzene, toluene, xylene), among others.

Population numbers were taken from state statistics as of January 01, 2021. ${ }^{2}$ At present approximately 3.46 million people live in the six cities examined in the present study.

Daily incidence of SARS-CoV-2 coronavirus infection was taken as the absolute number of cases over a period of time from April 18, 2020 to July 31, 2021, according to daily data provided by operative offices in the regions studied (overall, 77,337 disease cases).

Data analysis. Preliminary data preparation included the following:

- average daily concentrations of pollutants in the examined cities were computed via averaging data obtained from all daily measurements;

- gaps in initial data were filled due to averaging values of daily concentrations within a time range \pm 15 days from an examined date (in case there were 5 and more computed average daily concentrations);

- relative daily incidence among populations was computed as a ratio of an absolute number of registered cases to a population number;

- disease incidence was averaged per week (to remove "weekend effects" caused by peculiarities of medical aid provision and a system of accounting a number of people's applications for medical aid to medical organizations on weekends) as per the following formula (1):

$$
\tilde{y}_{t}^{7}=\frac{1}{7} \sum_{\tau=t-3}^{t+3} y_{\tau}
$$

where $\tilde{y}_{t}^{7}$ is incidence averaged over a 7-day period on a date $t$, cases $/ 1,000 ; t$ is the present date.

To model the epidemiologic process, we simplified the daily growth of disease cases by averaging data collected over a 28-day period using a moving-average procedure (2):

$$
\tilde{y}_{t}^{28}=\frac{1}{28} \sum_{\tau=t-14}^{t+13} y_{\tau},
$$

where $\tilde{y}_{t}^{28}$ is incidence on a date $t$ averaged over a 28 -day period, cases $/ 1,000, t$ is the present date.

Relationships were modeled in accordance with the basic hypothesis that a difference between detected incidence (with weekly averaging) and incidence in a basic epidemiologic scenario was due to external factors, including those related to air pollution.

To eliminate the influence exerted by a scale of a basic epidemiologic scenario in results obtained via assessing cause-and-effect

${ }^{2} 100$ largest cities in Russia as per population (2021). Available at: http://www.statdata.ru/largest_cities_russia (August 01, 2021). 
relations, a relative daily deviation was computed (3):

$$
\delta \tilde{y}_{t}=\frac{\tilde{y} \tilde{y}_{t}^{7}-\tilde{y}_{t}^{28}}{\tilde{y}_{t}^{28}},
$$

where $\delta \tilde{y}_{t}$ is a relative daily deviation in actual COVID-19 incidence from a basic epidemiologic scenario.

Computations of relative daily deviations for all six territories provided comparable standardized values such that all the data could be combined in a single data array for statistical analysis.

Modeling a system for cause-effect relations also involved correlation-regression analysis of relationships between a relative daily deviation in actual incidence from a basic scenario $\left(\delta \tilde{y}_{t}\right)$ among a given population and the average daily concentrations of chemicals in ambient air. Models were built based on combined data from all examined territories. In addition, we searched for a time gap between changes in air pollution rates and increased disease incidence. This optimal time lag was assumed to correspond to the maximum correlation coefficient.

Statistical analysis allowed relationships to be paired between relative daily growth in incidence and air pollution rates (4):

$$
\delta \tilde{y}_{t}=a_{i} x_{i, t-L i}+b_{i},
$$

where $x_{i, t-L i}$ is average daily concentration of the $i$-th chemical in ambient air on a date $t-L i$; $L i$ is time lag; $a_{i}, b_{i}$ are model coefficients for the $i$-th chemical.

Building models for relationships involved procedures aimed at testing statistical hypotheses regarding model parameters and model adequacy, as well as testing their biological plausibility.

Obtained models showing the relationships gave grounds for assessing a number of disease cases associated with ambient air pollution. To do that, the following values were calculated:

- daily incidence associated with ambient air pollution (5):

$$
\begin{aligned}
\Delta \tilde{y}_{t}=\sum_{i} \Delta \tilde{y}_{t, i} & =\sum_{i}\left(\delta \tilde{y}_{t}\left(x_{i, t-L i}\right)-\delta \tilde{y}_{t}(0)\right) \tilde{y}_{t}^{28}= \\
& =\sum_{i} a_{i} x_{i, t-L i} \tilde{y}_{t}^{28},
\end{aligned}
$$

where $\Delta \tilde{y}_{t}$ is total disease incidence associated with exposure to air pollution on a date $t$, cases $/ 1,000 ; \Delta \tilde{y}_{t, i}$ is disease incidence associated with exposure to the $i$-th chemical in ambient air on a date $t$, case $/ 1,000$;

- absolute number of disease cases associated with air pollution over a year (6):

$$
\Delta Y=\frac{N}{1000} \sum_{t} \Delta \tilde{y}_{t} .
$$

A probable contribution of air pollution to COVID-19-related mortality and morbidity among the populations studied was estimated based on the totality of data. Additionally, such a concentration of a chemical was computed that could account for permissible growth in COVID-19 incidence (target growth). The permissible (target) growth was taken as equal to $1 \%$ and / or $3 \%$ of a relative daily incidence for a given territory.

A target concentration was computed as per the following formula (7) that was obtained via transformation from the regression equation (5):

$$
x_{i}^{N}=\frac{\delta \tilde{y}^{N}}{a_{i}}
$$

where $x_{i}^{N}$ is a target concentration of the $i$-th chemical, $\mathrm{mg} / \mathrm{m}^{3} ; \delta \tilde{y}^{N}$ is a target relative growth in disease incidence taken as equal to 0.01 (or $1 \%$ ) or 0.03 (or $3 \%$ ).

The suggested approaches were tested in some cities that were included in the "Clean air" Federal project (Bratsk, Krasnoyarsk, Norilsk, Omsk, Cherepovets, and Lipetsk). Correlations between ambient air quality and COVID-19 spread were considered separately for each examined city due to specific chemicals occurring in ambient air in each of them and, accordingly, different programs for instrumental measurements that were applied there. 
We also attempted to reveal any common regularities by analyzing data combined for all six examined cities.

Basic results. Figures 3 and 4 show average weekly disease incidence for the examined territories. While similarities in the overall temporal pattern of disease incidence was evident in the six cities, individual cities showed variances one with the other.

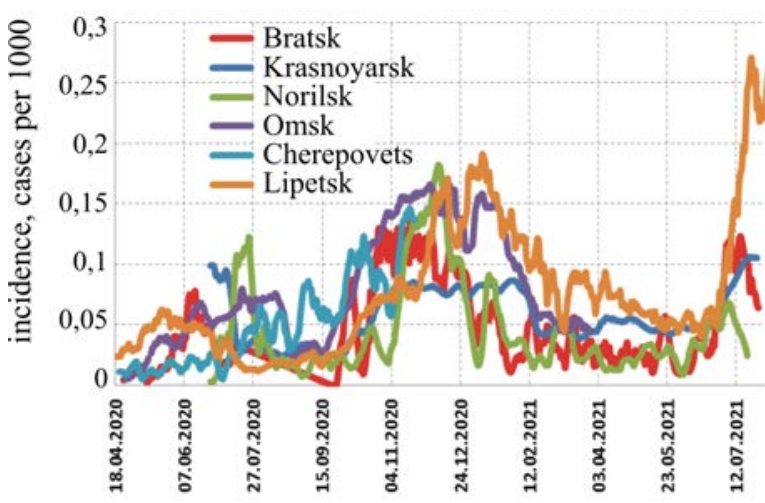

Figure 3. Daily incidence of SARS-CoV-2 on the examined territories averaged over a 7-day period
Assessment of a correlation between these deviations and air pollution rates in different cities allowed the development of several reliable mathematical models; Tables 1-3 contain their parameters for some cities (in these tables: $n$ is a number of daily observations, $R^{2}$ is determination coefficient).

Reliable models were obtained for a correlation between daily fluctuations in the

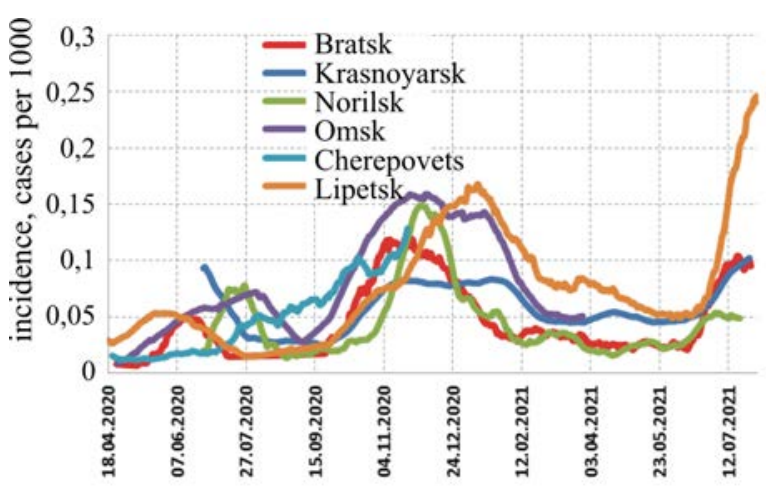

Figure 4. Daily incidence of SARS-CoV-2 according to a basic epidemiologic scenario (average over a 28day period)

Parameters of relationships between a value $\partial \tilde{y}_{t}$ and average daily concentrations of chemicals in ambient air $(p<0.05)$ in Bratsk

\begin{tabular}{|l|c|c|c|c|c|}
\hline \multicolumn{1}{|c|}{ Chemical } & $a_{i}$ & $b_{i}$ & $n$ & $R^{2}$ & $\begin{array}{c}\text { A range of daily concentrations over } \\
\text { the examined period, } \mathrm{mg} / \mathrm{m}^{3}\end{array}$ \\
\hline Benzopyrene & 41,600 & -0.0384 & 316 & 0.0225 & {$[0 * ; 1.42 \mathrm{E}-05]$} \\
\hline Particulate matter $\mathrm{PM}_{10}$ & 31.63 & -0.00356 & 321 & 0.0230 & {$[0 ; 0.036]$} \\
\hline Particulate matter $\mathrm{PM}_{2.5}$ & 20.87 & -0.00452 & 319 & 0.0165 & {$[0 ; 0.123]$} \\
\hline Hydrogen chloride & 9.19 & -0.027 & 316 & 0.0394 & {$[0 ; 0.06]$} \\
\hline Dimethylbenzene & 2.26 & -0.0935 & 309 & 0.0363 & {$[0 ; 0.35]$} \\
\hline Methylbenzene & 3.76 & -0.0817 & 309 & 0.0355 & {$[0 ; 0.17]$} \\
\hline Carbon (soot) & 2.24 & -0.0250 & 313 & 0.0199 & {$[0 ; 0.19]$} \\
\hline Ethylbenzene & 17.35 & -0.0719 & 309 & 0.0171 & {$[0 ; 0.022]$} \\
\hline
\end{tabular}

N o t e : $0^{*}$ - here and further on - means "lower than limit of detection".

Parameters of relationships between a value $\partial \tilde{y}_{t}$ and average daily concentrations of chemicals in ambient air $(p<0.05)$ in Cherepovets

\begin{tabular}{|l|c|c|c|c|c|}
\hline \multicolumn{1}{|c|}{ Chemical } & $a_{i}$ & $b_{i}$ & $N$ & $R^{2}$ & $\begin{array}{c}\text { A range of daily concentrations over } \\
\text { the examined period, } \mathrm{mg} / \mathrm{m}^{3}\end{array}$ \\
\hline Particulate matter $\mathrm{PM}_{10}$ & 6.04 & -0.0432 & 209 & 0.0597 & {$[0 ; 0.0707]$} \\
\hline Particulate matter $\mathrm{PM}_{2.5}$ & 5.28 & -0.0331 & 209 & 0.0349 & {$[0 ; 0.061]$} \\
\hline Nickel oxide * & 48.63 & -0.0465 & 209 & 0.0267 & {$[0 ; 0.00733]$} \\
\hline
\end{tabular}

$\mathrm{N}$ o t e : * occurs in ambient air as fine-dispersed solid particles. 
Table 3

Parameters of relationships between a value $\partial \tilde{y}_{t}$ and average daily concentrations of chemicals in ambient air $(p<0.05)$ in Lipetsk

\begin{tabular}{|l|c|c|c|c|c|}
\hline \multicolumn{1}{|c|}{ Chemical } & $a_{i}$ & $b_{i}$ & $n$ & $R^{2}$ & $\begin{array}{c}\text { A range of daily concentrations } \\
\text { over the examined period, } \mathrm{mg} / \mathrm{m}^{3}\end{array}$ \\
\hline Nitrogen dioxide & 0.593 & -0.0229 & 382 & 0.0104 & {$[0 ; 0.135]$} \\
\hline Ammonia & 2.78 & -0.0208 & 382 & 0.0207 & {$[0 ; 0.0506]$} \\
\hline Hydrogen sulphide & 119.6 & -0.00945 & 377 & 0.0104 & {$[0 ; 0.001]$} \\
\hline Manganese and its compounds* & 122.8 & -0.0122 & 375 & 0.0125 & {$[0 ; 9.75 \mathrm{E}-04]$} \\
\hline Ozone & 1.76 & -0.0223 & 382 & 0.0188 & {$[0 ; 0.0765]$} \\
\hline Prop-2-en-1-al (acrolein) & 57.4 & -0.0127 & 380 & 0.0104 & {$[0 ; 0.00263]$} \\
\hline
\end{tabular}

$\mathrm{N}$ o t e : * occurs in ambient air as fine-dispersed solid particles.

growth of COVID-19 cases and daily fluctuations in the airborne concentrations of benzene $\left(a_{i}=0.088 ; b_{i}=-0.0143 ; R^{2}=0.02\right)$ and hydrogen sulphide $\left(a_{i}=82.1 ; b_{i}=-0.063 ; R^{2}=0.32\right)$ in Krasnoyarsk; daily fluctuations in concentrations of nitrogen dioxide $\left(a_{i}=2,18 ; b_{i}=-0.0912\right.$; $\left.R^{2}=0.02\right)$ and sulfuric acid $\left(a_{i}=21,5\right.$; $\left.b_{i}=-0.099 ; R^{2}=0.11\right)$ in Norilsk; and daily fluctuations in concentrations of ethyl benzene $\left(a_{i}=2,96 ; b_{i}=-0.039 ; R^{2}=0.02\right)$ in Omsk.

Table 4 models the relationship between specific airborne pollutants using data from all examined cities and $\partial \tilde{y}_{t}$, which were considered authentic $(p<0.05)$.

Based on these mathematical models, we tentatively assessed the contribution made by chemical factors to the incidence of COVID-19 among populations in the examined cities (recalculated as per annual incidence) (Table 5).

Estimated contributions to COVID-19 incidence from airborne pollutants varied from $1.6 \%$ (Krasnoyarsk) to $8.9 \%$ (Norilsk) in five of six examined cities, results that compare well with those reported from studies outside the Russian Federation. Results obtained for the city of Bratsk fall outside this range since the computed contribution for chemical factors amounted to almost one third over the examined period.

Overall, approximately 3,572 number of COVID-19 cases detected in the examined cities are probabilistically related to polluted breathable air. This suggests that decreased air pollution would reduce the number of COVID-19 cases in these cities and beyond.

Tables 6-11 contain results obtained via computing target levels of admixture contents in ambient air for each city.

Target concentrations differ by city due to the differential estimated total health impact of city-specific air pollutants. However, almost everywhere, the target air pollutant levels that ensure a growth in COVID-19 incidence not exceeding $3 \%$, and in a better case $1 \%$, are lower than the average daily maximum permissible concentration (MPC) of an individual

Table 4

Parameters of relationships between a value $\partial \tilde{y}_{t}$ and average daily concentrations of chemicals in ambient air as per combined data collected in all 6 cities

\begin{tabular}{|l|c|c|c|c|}
\hline Chemical & $a_{i}$ & $b_{i}$ & $n$ & $R^{2}$ \\
\hline Hydrogen chloride (as per HCl molecule) & 8.96 & -0.0202 & 464 & 0.0369 \\
\hline di-Aluminum trioxide * & 7.34 & -0.0213 & 591 & 0.0105 \\
\hline Nickel oxide (recalculated as per Ni)* & 39.8 & -0.0298 & 619 & 0.0126 \\
\hline Ozone & 1.76 & -0.0223 & 382 & 0.0188 \\
\hline Carbon black (soot)* & 1.39 & -0.0135 & 1469 & 0.0077 \\
\hline Formaldehyde & 2.09 & -0.0146 & 1372 & 0.0036 \\
\hline
\end{tabular}

$\mathrm{N}$ o t e : * occurs in ambient air as fine-dispersed solid particles. 
Computed numbers of associated disease cases as per cities, cases/year

\begin{tabular}{|c|c|c|c|c|c|}
\hline \multirow{3}{*}{ City } & \multicolumn{4}{|c|}{ COVID-19 incidence over the examined period } & \multirow{3}{*}{$\begin{array}{c}\text { Share of cases } \\
\text { associated with air } \\
\text { pollution }\end{array}$} \\
\hline & \multicolumn{2}{|c|}{ Actually detected } & \multicolumn{2}{|c|}{ Including that associated with air pollution } & \\
\hline & Cases, total & cases / 1,000 & Cases, total & cases / 1,000 & \\
\hline Bratsk & 3,280 & 14.50 & 1,380 & 6.10 & 0.334 \\
\hline Krasnoyarsk & 14,929 & 14.83 & 232 & 0.23 & 0.016 \\
\hline Norilsk & 2,171 & 11.94 & 207 & 1.14 & 0.089 \\
\hline Omsk & 33,238 & 28.79 & 723 & 0.63 & 0.022 \\
\hline Cherepovets & 5,634 & 18.05 & 501 & 1.61 & 0.089 \\
\hline Lipetsk & 15,326 & 30.46 & 529 & 1.05 & 0.035 \\
\hline
\end{tabular}

Table 6

Target average daily concentrations of chemicals in ambient air in Bratsk that ensure a relative growth in COVID-19 incidence not exceeding 1-3\% (here and further on given a persistent set of pollutants typical for a specific city)

\begin{tabular}{|c|c|c|c|c|}
\hline \multirow[t]{2}{*}{ Chemical } & \multicolumn{2}{|c|}{$\begin{array}{l}\text { Target concentration, } \mathrm{mg} / \mathrm{m}^{3} \text {, that ensures growth } \\
\text { in incidence not exceeding }\end{array}$} & \multicolumn{2}{|c|}{$\mathrm{MPC}^{*}, \mathrm{mg} / \mathrm{m}^{3}$} \\
\hline & $1 \%$ & $3 \%$ & av.daily & av.annual \\
\hline Benzopyrene & $2.40 \mathrm{E}-07$ & $7.2 \mathrm{E}-07$ & - & $1.00 \mathrm{E}-06$ \\
\hline Particulate matter $\mathrm{PM}_{10}$ & 0.0003 & 0.0010 & 0.15 & 0.075 \\
\hline Particulate matter $\mathrm{PM}_{2.5}$ & 0.0005 & 0.0014 & 0.035 & 0.025 \\
\hline Hydrogenchloride (as per $\mathrm{HCl}$ molecule) & 0.0011 & 0.003 & 0.1 & 0.02 \\
\hline Dimethylbenzene (a mix of isomers) & 0.0044 & 0.013 & 0.04 & - \\
\hline Methylbenzene & 0.0027 & 0.008 & - & - \\
\hline Carbon (soot) & 0.0045 & 0.013 & 0.05 & 0.025 \\
\hline Ethylbenzene & 0.0006 & 0.002 & - & 0.04 \\
\hline
\end{tabular}

N o t e : *MPC means maximum permissible concentration.

Table 7

Target average daily concentrations of chemicals in ambient air in Cherepovets that ensure a relative growth in COVID-19 incidence not exceeding 1-3\%

\begin{tabular}{|l|c|c|c|}
\hline \multirow{2}{*}{\multicolumn{1}{|c|}{ Chemical }} & \multicolumn{2}{|c|}{$\begin{array}{c}\text { Target concentration, } \mathrm{mg} / \mathrm{m}^{3} \text {, that ensures growth } \\
\text { in incidence not exceeding }\end{array}$} & $\begin{array}{c}\text { MPC av.daily, } \\
\mathrm{mg} / \mathrm{m}^{3}\end{array}$ \\
\cline { 2 - 3 } & $1 \%$ & $3 \%$ & 0.06 \\
\hline Particulate matter $\mathrm{PM}_{10}$ & 0.0017 & 0.051 & 0.035 \\
\hline Particulate matter $\mathrm{PM}_{2.5}$ & 0.0019 & 0.006 & 0.001 \\
\hline Nickel oxide & 0.0002 & 0.001 & 0.01 \\
\hline
\end{tabular}

Table 8

Target average daily concentrations of chemicals in ambient air in Lipetsk that ensure a relative growth in COVID-19 incidence not exceeding 1-3\%

\begin{tabular}{|c|c|c|c|}
\hline \multirow[t]{2}{*}{ Chemical } & \multicolumn{2}{|c|}{$\begin{array}{l}\text { Target concentration, } \mathrm{mg} / \mathrm{m}^{3} \text {, that ensures growth } \\
\text { in incidence not exceeding }\end{array}$} & \multirow{2}{*}{$\begin{array}{c}\mathrm{MPC} \\
\text { av.daily, } \\
\mathrm{mg} / \mathrm{m}^{3}\end{array}$} \\
\hline & $1 \%$ & $3 \%$ & \\
\hline Nitrogen oxide & 0.017 & 0.051 & 0.06 \\
\hline Ammonia & 0.004 & 0.012 & 0.035 \\
\hline Hydrogen sulphide & 0.00008 & 0.001 & 0.001 \\
\hline Manganese and its compounds & 0.00008 & 0.0003 & $0.002 *$ \\
\hline Ozone & 0.006 & 0.018 & 0.1 \\
\hline Prop-2-en-1-al (acrolein) & 0.0002 & 0.0006 & 0.01 \\
\hline
\end{tabular}

$\mathrm{N}$ ot e : * average annual concentration is given in case there is no determine average daily one. 
Target average daily concentrations of chemicals in ambient air in Norilsk that ensure a relative growth in COVID-19 incidence not exceeding 1-3\%

\begin{tabular}{|l|c|c|c|}
\hline \multirow{2}{*}{\multicolumn{1}{c|}{ Chemical }} & \multicolumn{2}{|c|}{$\begin{array}{c}\text { Target concentration, } \mathrm{mg} / \mathrm{m}^{3} \text {, that ensures growth } \\
\text { in incidence not exceeding }\end{array}$} & \multirow{2}{*}{$\begin{array}{c}\mathrm{MPC} \text { av.daily, } \\
\mathrm{mg} / \mathrm{m}^{3}\end{array}$} \\
\cline { 2 - 3 } & $1 \%$ & $3 \%$ & 0.06 \\
\hline Nitrogen dioxide & 0.0046 & 0.42 & $0.002^{*}$ \\
\hline Hydrogen sulphide & 0.0005 & 0.0004 & \\
\hline
\end{tabular}

$\mathrm{N}$ o t e : * average annual concentration is given in case there is no determine average daily one.

Table 10

Target average daily concentrations of chemicals in ambient air in Krasnoyarsk that ensure a relative growth in COVID-19 incidence not exceeding 1-3\%

\begin{tabular}{|l|c|c|c|}
\hline \multicolumn{1}{|c|}{ Chemical } & \multicolumn{2}{c|}{$\begin{array}{c}\text { Target concentration, } \mathrm{mg} / \mathrm{m}^{3} \text {, that ensures growth } \\
\text { in incidence not exceeding }\end{array}$} & $\begin{array}{c}\mathrm{MPC} \text { av.daily, } \\
\mathrm{mg} / \mathrm{m}^{3}\end{array}$ \\
\hline & $1 \%$ & $3 \%$ & \\
\hline Benzene & 0.1136 & 0.42 & 0.06 \\
\hline Hydrogen sulphide & 0.00012 & 0.0004 & $0.002^{*}$ \\
\hline
\end{tabular}

$\mathrm{Note}: *$ average annual concentration is given in case there is no determine average daily one.

Table 11

Target average daily concentrations of chemicals in ambient air in Omsk that ensure a relative growth in COVID-19 incidence not exceeding 1-3\%

\begin{tabular}{|l|c|c|c|}
\hline \multirow{2}{*}{ Chemical } & \multicolumn{2}{|c|}{$\begin{array}{c}\text { Target concentration, } \mathrm{mg} / \mathrm{m}^{3} \text {, that ensures growth } \\
\text { in incidence not exceeding }\end{array}$} & \multirow{2}{*}{$\begin{array}{c}\mathrm{MPC} \text { av.daily, } \\
\mathrm{mg} / \mathrm{m}^{3}\end{array}$} \\
\cline { 2 - 3 } & $1 \%$ & $3 \%$ & $0.04^{*}$ \\
\hline Ethylbenzene & 0.0037 & 0.011 & 0.001 \\
\hline Nickel oxide & 0.00004 & 0.0001 & \\
\hline
\end{tabular}

$\mathrm{N}$ o t e : * average annual concentration is given in case there is no determine average daily one.

pollutant and/or average annual MPC. A target level may be lower than hygienic standards by 1.5-3 times (for example, target concentrations of nitrogen dioxide and ammonia in Lipetsk; benzopyrene and xylene in Bratsk, or particulate matter $\mathrm{PM}_{10}$ in Cherepovets) or even by 10-20 times (target concentrations of manganese compounds and acrolein in Lipetsk or hydrogen sulphide in Krasnoyarsk). While target concentrations are determined by specific sets of pollutants in this or that city and actual existing concentrations of specific admixtures, the data overall predict that COVID19 cases would drop with substantial improvement in ambient air quality.

Discussion. The present results support the hypothesis that variations in COVID-19 incidence is correlated with urban air pollution, and that these relationships are demonstrable re- gardless of the type and concentration of pollutants in breathable air. In brief, air pollution appears to increase the incidence of COVID-19. This relationship holds not only for particulate matter (as reported in multiple foreign publications) but also for a set of other chemicals that produce airway irritability among other physiologic effects. These chemicals include: sulfuric acid vapors, hydrogen chloride, formaldehyde, hydrogen sulphide, among others.

The apparent contribution of chemical pollution to an increased COVID-19 incidence in five of the six cities (i.e., Krasnoyarsk, Norilsk, Omsk, Cherepovets, and Lipetsk) varied within close ranges and amounted to approximately $5.0 \pm 2.6 \%$ over the examined period. A detected correlation between daily fluctuations in COVID-19 incidence and air pollution in Bratsk was substantially more intense and 
amounted to approximately $33 \%$; additional research is required either to confirm or correct these results. Overall, these results assume that pre-existing disease and other factors that affect COVID-19 rates are distributed equally among the populations studied here. The findings also rely on the assumption that COVID-19 incidence is comparably reported across the cities studied. While COVID-19 mortality rates are not included, such data would be a valuable addition to the present analysis.

These results are relevant to economic entities that contribute to air pollution and to the governmental authorities that regulate the emission of pollutants from factories and other entities. Standards for permissible emissions can and should be the first obligatory step in making the living environment truly safe, but there should also be further measures designed to minimize air pollution and associated population health risks. Such steps are especially important when people are simultaneously exposed to a contagious respiratory virus (SARS-CoV-2) and air pollutants that are known to compromise airway and/or immune function. The latter should always be taken into account when a system for environmental standardization is being updated, including methodology for emissions quoting. Indeed, the management of pollutant emissions in cities should become a system for health risk management, especially in the case of specific sanitary-epidemiologic situations. These recommendations are highlighted by the present results showing that COVID-19 has uncovered underlying major health risks among urban populations in Russia and beyond that are continually exposed to airborne pollutants.

The present research is considered to be preliminary and aimed at testing methodological approaches. Primary analysis of all collected data revealed some uncertainties in initial data that produced significant effects on computation results and should be eliminated. Uncertainties are associated with some delay in entering data on morbidity into information bases and the lack of measurements for some days, which required "restoration" of data by interpolation methods.
Similar studies using more complete data collected over a longer period of time are recommended. Additionally, it will be important to examine how air pollution affects COVID-19 incidence and mortality by sex, age, occupation and preexisting medical conditions. Results obtained from such studies will allow the development of recommendations designed to optimize the quality of breathable urban air.

Studies on the efficiency of vaccination against SARS-CoV-2 and post-vaccination immunity persistence among people living under different external exposure conditions can be and should be another significant trend in future research. Such studies should be accomplished as soon as possible since they, among other things, are vital for organizing proper and efficient prevention of repetitive waves of COVID-19. Without doubt, there are grounds for such studies: first of all, there is evidence of declining post-vaccination immunity to other communicable diseases such as measles or diphtheria under exposure to environmental pollution [37-39]. Research [40] has shown that laboratory blood tests of children living in environments with permanent high chemical aerotechnogenic exposure have weakened immune systems and decreased immune responses to vaccine antigens.

Given the existence of a relevant database, wide-scale research that focuses on assessing the influence of environmental pollution on preserving immunity against COVID-19 could be launched without delay. Ambient air quality is constantly monitored within the "Ecology" National project in residential areas in cities where air pollution is high. Data on each COVID-19 case are registered in a unified database that contains information collected across Russia. There is also systemic national serologic monitoring [41] that provides uninterrupted objective assessment of specific post-vaccination immunity against agents of communicable diseases that can be managed via specific prevention; this monitoring is performed in "indicator" population groups and risk groups.

There should be permanent control over the existing situation, and wide and compre- 
hensive discussion of the results obtained via this control; discussion and communications should involve not only scientists and practical experts in public health but also people who make decisions on ecology, medicine, public agents at all levels, and people representing business and civil society as well. All the abovelisted steps are needed not only to control and surmount the current pandemic but also to provide critical information to help solve similar problems in future. These approaches are in line with opinions and attitudes expressed by many researchers [42-44].

Conclusions. An authentic correlation between COVID-19 incidence and the concentration of chemical pollutants in ambient air has been detected in all six examined cities; these are considered priority cities in the Russian Federation for air pollution and are included in the "Clean air" Federal project. Our data are in line with those obtained by foreign researchers and suggest a common trend of higher COVID-19 incidence among people living in urbanized territories of Russia and beyond. In sum, they suggest that continuous exposure to certain air pollutants with established adverse health impacts can increase the risk of COVID-19 and spread of SARS-CoV-2.

In five cities (Krasnoyarsk, Norilsk, Omsk, Cherepovets, and Lipetsk), the contributed excess risk varied within close ranges and amounted to approximately $5.0 \pm 2.6 \%$ over the test period. A detected correlation between daily fluctuations in the growth in COVID-19 incidence and air pollution in Bratsk was substantially more intense and amounted to approximately $33 \%$. This unexpected large result requires confirmation based on a more detailed analysis of modeled data.
Combined multi-component exposure to chemicals results in an authentic growth in medical and demographic losses even if concentrations of specific chemicals conform to hygienic standards. Standards for permissible emissions should be treated as the first obligatory stage in making the living environment truly safe, but in future there should be further actions aimed at minimizing pollution and population health risks.

The present research allowed testing some methodological approaches to detect fluctuations in COVID-19 incidence associated with air pollution. It seems advisable to accomplish similar studies using more complete data collected over a longer period of time, including examinations focusing on mortality due to COVID-19, especially among urban populations in Russia and beyond.

Studies on the efficiency of vaccination against SARS-CoV-2 and post-vaccination immunity persistence among people living under different environmental conditions should become another significant trend in future research.

The combination of epidemiologic trends and biomedical examinations that concentrate on the efficiency of SARS-CoV-2 vaccination can provide a scientific information base for the optimal management of environmental quality and population health risks; among other things, it helps prevent and control negative outcomes during complicated sanitary epidemiologic situations.

Funding. The research was not granted any financial support.

Conflict of interests. The authors declare there is no any conflict of interests.

\section{References}

1. Becker S., Soukup J.M. Exposure to urban air particulates alters the macrophage-mediated inflammatory response to respiratory viral infection. J. Toxicol. Environ. Health A., 1999, vol. 57, no. 7, pp. 445-457. DOI: 10.1080/009841099157539

2. Cui Y., Zhang Z.-F., Froines J., Zhao J., Wang H., Yu S.-Z., Detels R. Air pollution and case fatality of SARS in the People's Republic of China: an ecologic study. Environ. Heath, 2003, vol. 2, no. 1, pp. 15. DOI: 10.1186/1476-069X-2-15

3. Ciencewicki J., Jaspers I. Air pollution and respiratory viral infection. Inhal. Toxicol., 2007, vol. 19, no. 14, pp. 1135-1146. DOI: 10.1080/08958370701665434 
4. Troeger C., Forouzanfar M., Rao P.C., Khalil I., Brown A., Swartz S., Fullman N., Mosser J. [et al.]. Estimates of the global, regional, and national morbidity, mortality, and aetiologies of lower respiratory tract infections in 195 countries: a systematic analysis for the Global Burden of Disease Study 2015. Lancet Infect. Dis., 2017, vol. 17, no. 11, pp. 1133-1161. DOI: 10.1016/S14733099(17)30396-1

5. Su W., Wu X., Geng X., Zhao X., Liu Q., Liu T. The short-term effects of air pollutants on influenza-like illness in Jinan, China. BMC Public Health, 2019, vol. 19, no. 1, pp. 1319. DOI: 10.1186/s12889-019-7607-2

6. Gordon S.B., Bruce N.G., Grigg J., Hibberd P.L., Kurmi O.P., Lam K.B., Mortimer K., Asante K.P. [et al.]. Respiratory risks from household air pollution in low and middle income countries. Lancet Respir. Med., 2014, vol. 2, no. 10, pp. 823-860. DOI: 10.1016/S2213-2600(14)70168-7

7. GBD 2016 Lower Respiratory Infections Collaborators. Estimates of the global, regional, and national morbidity, mortality, and aetiologies of lower respiratory infections in 195 countries, 1990-2016: a systematic analysis for the Global Burden of Disease Study 2016. Lancet Infect. Dis., 2018, vol. 18, no. 11, pp. 1191-1210. DOI: 10.1016/S1473-3099(18)30310-4

8. Wolkoff P. Indoor air humidity, air quality, and health - An overview. Int. J. Hyg. Environ. Health, 2018, vol. 221, no. 3, pp. 376-390. DOI: 10.1016/j.ijheh.2018.01.015

9. Katoto P.D.M.C., Brand A.S., Bakan B., Obadia P.M., Kuhangana C., Kayembe-Kitenge T., Kitenge J.P., Nkulu C.B.L. [et al.]. Acute and chronic exposure to air pollution in relation with incidence, prevalence, severity and mortality of COVID-19: a rapid systematic review. Environ. Health, 2021, vol. 20, no. 1, pp. 41. DOI: 10.1186/s12940-021-00714-1

10. Zoran M.A., Savastru R.S., Savastru D.M., Tautan M.N. Assessing the relationship between ground levels of ozone $\left(\mathrm{O}_{3}\right)$ and nitrogen dioxide $\left(\mathrm{NO}_{2}\right)$ with coronavirus (COVID-19) in Milan, Italy. Sci. Total Environ., 2020, vol. 740, pp. 140005. DOI: 10.1016/j.scitotenv.2020.140005

11. Comunian S., Dongo D., Milani C., Palestini P. Air pollution and COVID-19: The role of particulate matter in the spread and increase of COVID-19's morbidity and mortality. Int. J. Environ. Res. Public Health, 2020, vol. 17, no. 12, pp. 4487. DOI: 10.3390/ijerph17124487

12. Villeneuve P.J., Goldberg M.S. Methodological considerations for epidemiological studies of air pollution and the SARS and COVID-19 coronavirus outbreaks. Environ. Health Perspect., 2020, vol. 128, no. 9, pp. 95001. DOI: 10.1289/EHP7411

13. Chakraborty P., Jayachandran S., Padalkar P., Sitlhou L., Chakraborty S., Kar R., Bhaumik S., Srivastava M. Exposure to nitrogen dioxide $\left(\mathrm{NO}_{2}\right)$ from vehicular emission could increase the COVID-19 pandemic fatality in India: a perspective. Bull. Environ. Contam. Toxicol., 2020, vol. 105, no. 2, pp. 198-204. DOI: $10.1007 / \mathrm{s} 00128-020-02937-3$

14. Fattorini D., Regoli F. Role of the chronic air pollution levels in the COVID-19 outbreak risk in Italy. Environ. Pollut., 2020, vol. 264, pp. 114732. DOI: 10.1016/j.envpol.2020.114732

15. Vasquez-Apestegui V., Parras-Garrido E., Tapia V., Paz-Aparicio V.M., Rojas J.P., SánchezCcoyllo O.R., Gonzales G.F. Association between air pollution in Lima and the high incidence of COVID-19: findings from a post hoc analysis. Res. Sq., 2020, vol. 3, pp. 39404. DOI: 10.21203/rs.3.rs-39404/v1

16. Frontera A., Cianfanelli L., Vlachos K., Landoni G., Cremona G. Severe air pollution links to higher mortality in COVID-19 patients: the "double-hit" hypothesis. J. Inf. Secur., 2020, vol. 81, no. 2, pp. 255-259. DOI: 10.1016/j.jinf.2020.05.031

17.Transmission of SARS-CoV-2: implications for infection prevention precautions: scientific brief, 09 July 2020. WHO, 2020, 10 p. Available at: https://apps.who.int/iris/bitstream/handle/10665/333114/WHO2019-nCoV-Sci_Brief-Transmission_modes-2020.3-eng.pdf?sequence=1\&isAllowed=y (19.08.2021).

18.Van Doremalen N., Bushmaker T., Morris D.H., Holbrook M.G., Gamble A., Williamson B.N., Tamin A., Harcourt J.L. [et al.]. Aerosol and surface stability of SARS-CoV-2 as compared with SARS-CoV-1. New England Journal of Medicine, vol. 382, no. 16, pp. 1564-1567. DOI: 10.1056/NEJMc2004973

19. Wu X., Nethery R.C., Sabath M.B., Braun D., Dominici F. Exposure to air pollution and COVID-19 mortality in the United States: A nationwide cross-sectional study. MedRxiv, 2020. DOI: $10.1101 / 2020.04 .05 .20054502$

20. Setti L., Passarini F., De Gennaro G., Barbieri P., Licen S., Perrone M.G., Piazzalunga A., Borelli M. [et al.]. Potential role of particulate matter in the spreading of COVID-19 in Northern Italy: 
first observational study based on initial epidemic diffusion. BMJ Open, 2020, vol. 10, no. 9, pp. e039338. DOI: 10.1136/bmjopen-2020-039338

21. Zhu Y., Xie J., Huang F., Cao L. Association between short-term exposure to air pollution and COVID-19 infection: evidence from China. Sci. Total Environ., 2020, vol. 727, pp. 138704. DOI: 10.1016/j.scitotenv.2020.138704

22. Bontempi E. First data analysis about possible COVID-19 virus airborne diffusion due to air particulate matter (PM): the case of Lombardy (Italy). Environ. Res., 2020, vol. 186, pp. 109639. DOI: 10.1016/j.envres.2020.109639

23. Giani P., Castruccio S., Anav A., Howard D., Hu W., Crippa P. Short-term and long-term health impacts of air pollution reductions from COVID-19 lockdowns in China and Europe: a modelling study. Lancet Planetary Health, 2020, vol. 4, no. 10, pp. e474-e482. DOI: 10.1016/S2542-5196(20)30224-2

24. Domingo J.L., Marquès M., Rovira J. Influence of airborne transmission of SARS-CoV-2 on COVID-19 pandemic. A review. Environmental Research, 2020, vol. 188, pp. 109861. DOI: 10.1016/j.envres.2020.109861

25.Copat C., Cristaldi A., Fiore M., Grasso A., Zuccarello P., Signorelli S.S., Oliveri G., Ferrante C.M. The role of air pollution (PM and $\mathrm{NO}_{2}$ ) in COVID-19 spread and lethality: a systematic review. Environ. Res., 2020, vol. 191, pp. 110129. DOI: 10.1016/j.envres.2020.110129

26. Bourdrel T., Annesi-Maesano I., Alahmad B., Maesano C.N., Bind M.-A. The impact of outdoor air pollution on COVID-19: a review of evidence from in vitro, animal, and human studies. Europ. Respir. Rev., 2021, vol. 30, no. 159, pp. 200242. DOI: 10.1183/16000617.0242-2020

27. Khan M.M.A., Khan M.N., Mustagir M.G., Rana J., Islam M.S., Kabir M.I. Effects of underlying morbidities on the occurrence of deaths in COVID-19 patients: a systematic review and meta-analysis. J. Glob. Health, 2020, vol. 10, no. 2, pp. 020503. DOI: 10.7189/jogh.10.020503

28. Bornstein S.R., Voit-Bak K., Schmidt D., Morawietz H., Bornstein A.B., Balanzew W., Julius U., Rodionov R.N. [et al.]. Is there a role for environmental and metabolic factors predisponsing to severe COVID-19. Horm. Metab. Res., 2020, vol. 52, no. 7, pp. 540-546. DOI: 10.1055/a-1182-2016

29. Ogen Y. Assessing nitrogen dioxide $\left(\mathrm{NO}_{2}\right)$ levels as a contributing factor to coronavirus (COVID-19) fatality. Sci. Total. Environ., 2020, vol. 726, pp. 138605. DOI: 10.1016/j.scitotenv.2020.138605

30. Zagorodnov S. Dust contamination of the atmospheric air of the city as an undervalued risk factor to human health. Vestnik Permskogo natsional'nogo issledovatel'skogo politekhnicheskogo universiteta. Prikladnaya ekologiya. Urbanistika, 2018, no. 2 (30), pp. 124-133. DOI: 10.15593/24095125/2018.02.10 (in Russian).

31. Kleyn S.V., Zaitseva N.V., Vekovshinina S.A., Andrishunas A.M. Ambient air quality factors and people health. 20th International Multidisciplinary Scientific GeoConference SGEM 2020, 2020, vol. 20, pp. 115-124. Available at: https://www.sgem.org/index.php/elibrary?view=publication\&task=show\&id=7663 (02.09.2021).

32. Klyuev N.N., Yakovenko L.M. "Dirty" cities in Russia: factors determining air pollution. Vestnik Rossiiskogo universiteta druzhby narodov. Seriya: Ekologiya i bezopasnost' zhiznedeyatel'nosti, 2018, vol. 26, no. 2, pp. 237-250. DOI: 10.22363/2313-2310-2018-26-2-237-250 (in Russian).

33. Revich B.A. Natsional'nyi proekt "Chistyi vozdukh" v kontekste okhrany zdorov'ya naseleniya [National "Clean Air" Project in the context of public health protection]. Ekologicheskii vestnik Rossii, 2019, no. 4, pp. 64-69 (in Russian).

34. Kleyn S.V., Popova E.V. Hygienic assessment of ambient air quality in Chita, a priority area of the Federal "Clean Air" Project. Zdorov'e naseleniya i sreda obitaniya, 2020, no. 12 (333), pp. 31-37 (in Russian).

35. Maksimova E.V., Kokoulina A.A., Perezhogin A.N., Zhdanova-Zaplesvichko I.G. Gigienicheskaya otsenka kachestva atmosfernogo vozdukha g. Bratska do realizatsii meropriyatii federal'nogo proekta "Chistyi vozdukh" [Hygienic assessment of the quality of atmospheric air in Bratsk before the implementation of the measures of the "Clean Air" Federal Project]. Analiz riska zdorov'yu - 2020 sovmestno s mezhdunarodnoi vstrechei po okruzhayushchei srede i zdorov'yu Rise-2020 i kruglym stolom po bezopasnosti pitaniya: materialy $X$ Vserossiiskoi nauchno-prakticheskoi konferentsii s mezhdunarodnym uchastiem. In: A.Yu. Popova, N.V. Zaitseva eds., 2020, pp. 273-278 (in Russian).

36. On the state of sanitary and epidemiological well-being of the population in the Russian Federation in 2020: State report. Moscow, Federal Service for Supervision of Consumer Rights Protection 
and Human Welfare, 2021. Available at: https://www.rospotrebnadzor.ru/upload/iblock/5fa/gdseb_02.06-_s-podpisyu_.pdf (01.09.2021) (in Russian).

37. Scherbatyuk A. Comparative estimation of environmental safety of air of some Russian Federation's federal districts. Vestnik Zabaikal'skogo gosudarstvennogo universiteta, 2017, vol. 23, no. 9, pp. 53-66. DOI: 10.21209/2227-9245-2017-23-9-53-66 (in Russian).

38. Ilyina S.V., Stepanenko L.A., Kiklevich V.T., Gavrilova T.A., Savilov E.D. Vaktsinoprofilaktika poliomielita zhivoi poliovaktsinoi $\mathrm{v}$ usloviyakh ekologicheskogo neblagopoluchiya [Vaccine prophylaxis of poliomyelitis with live polio vaccine in environmental conditions]. Sibirskii meditsinskii zhurnal (Irkutsk), 2005, vol. 56, no. S7, pp. 48-49 (in Russian).

39. Ilyina S.V., Dronova M.A., Kiklevich V.T., Savilov Ye. D., Briko N.I. Pertussis in children in high technogenically polluted 18 environmental areas. Epidemiologiya i infektsionnye bolezni, 2007, no. 1, pp. 18-20 (in Russian).

40. Makarova V., Ustinova O.Yu., Dolgikh O.V., Zagumennyh A.D. Immune profile and postvaccinal immune status for infections, controlled by the immunoprophylaxis implements for children under the combined aerogenic exposition by chemical anthropogenic substances. Zdorov'e naseleniya i sreda obitaniya, 2013, no. 11 (248), pp. 27-29 (in Russian).

41. Popova A.Yu., Ezhlova E.B., Mel'nikova A.A., Balakhonov S.V., Chesnokova M.V., Dubrovina V.I., Lyalina L.V., Smirnov V.S. [et al.]. Experience in studying seroprevalence to SARS-CoV-2 virus in the population of the Irkutsk region during COVID-19 outbreak. Problemy osobo opasnykh infektsii, 2020, no. 3, pp. 106-113 (in Russian).

42. Anderson R.M., Heesterbeek H., Klinkenberg D., Hollingsworth T.D. How will country-based mitigation measures influence the course of the COVID-19 epidemic? The Lancet, 2020, vol. 395, no. 10228 , pp. 931-934. DOI: 10.1016/s0140-6736(20)30567-5

43. Salathé M., Althaus C.L., Neher R., Stringhini S., Hodcroft E., Fellay J., Zwahlen M., Senti G. [et al.]. COVID-19 epidemic in Switzerland: On the importance of testing, contact tracing and isolation. Swiss. Med. Wkly, 2020, vol. 150, pp. w20225. DOI: 10.4414/smw.2020.20225

44. Padron-Regalado E. Vaccines for SARS-CoV-2: Lessons from other coronavirus strains. Infect. Dis. Ther., 2020, vol. 9, no. 2, pp. 1-20. DOI: 10.1007/s40121-020-00300-x

Zaitseva N.V., May I.V., Reis J., Spenser P., Kiryanov D.A., Kamaltdinov M.R. On estimating the additional incidence of covid-19 among populations exposed to polluted ambient air: methodical approaches and some practical results. Health Risk Analysis, 2021, no. 3, pp. 14-28. DOI: 10.21668/health.risk/2021.3.02.eng

Received: 30.04 .2021

Accepted: 23.09.2021

Published: 30.09 .2021 